\title{
Seasonal participation in maize markets in Zambia: Do agricultural input subsidies and gender matter?
}

\author{
Franklin Simtowe ${ }^{1}$ (D) Hugo De Groote ${ }^{1}$ \\ Received: 4 September 2019 / Accepted: 7 September 2020 / Published online: 22 September 2020 \\ (C) The Author(s) 2020
}

\begin{abstract}
This paper uses data from 1128 households drawn from 35 districts, three agroecological zones and five provinces in Zambia to explore the influence of gender and other parameters on seasonal maize market participation. We apply a multivariate regression and the Blinder-Oaxaca decomposition technique to identify determinants of seasonal market participation and to decompose the differences in market participation outcomes between male headed and female headed households, respectively. About $10 \%$ of the households were 'selling low and buying high' which, through the supply enhancement effect, fertiliser subsidies and credit, enhanced maize selling soon after harvest while reducing the propensity to purchase in the lean season, an indication of the positive effect on food self-sufficiency. Significant market participation gaps were observed between male and female headed households in both seasons, with more female headed households purchasing maize soon after harvest and less of it in the lean season than their male counterparts. These differences were attributable to endowment effects. The study recommends policies that promote equitable access to production resources, such as the land, in order to reduce the gaps in market participation between men and women and for them to take advantage of the inter-seasonal maize price movements.
\end{abstract}

Keywords Maize $\cdot$ Seasonal marketing $\cdot$ Gender $\cdot$ Input subsidies $\cdot$ Zambia

\section{Introduction}

Development experts understand why small farmers stand to benefit from greater engagement with markets, both for increasing output for sale, as well as greater access to inputs and services that can raise productivity. Markets allow farmers to benefit from increased production by selling the surplus, allowing them to get extra income, which can be used to purchase other food and non-food items, including inputs such as improved seed, fertiliser, chemicals and machinery for increased productivity. Some literature (Heltberg and Tarp 2002; Pingali 2007) contends that such benefits at a household level have a positive impact on economic growth. However,

Franklin Simtowe

f.simtowe@cgiar.org

Hugo De Groote h.degroote@CGIAR.ORG

1 International Maize and Wheat Improvement Center (CIMMYT), ICRAF House, United Nations Avenue - Gigiri, P.O. Box 1041-00621, Nairobi, Kenya smallholder farmers are not homogenous, and therefore, some may face barriers to participation in these markets.

Sibande et al. (2017), Alene et al. (2008) and Barrett (2008) summarise that such barriers include poor infrastructure; high transaction costs of marketing; large input requirements in the form of land, chemicals, fertilizer and processing; and information asymmetry, among others.

There is a three-fold motivation to this paper: $i)$ the impact of seasonality and type or market participation; ii) the impact of public interventions in the market, and iii) gendered barriers to market access. The first motivation relates to the seasonality and type of market participation, whether as a buyer or as a seller. As expressed by Stephens and Barrett (2011), smallholder maize farmers in developing countries may sell maize soon after harvest when prices are low and buy it again from the market when prices are higher. This 'seemingly' irrational behaviour of 'sell low - buy high' by small scale producers reflects a loss to the producing households and merits understanding in order to inform appropriate interventions. Some studies have analysed seasonal market participation (Burke et al. 2018: Stephens and Barrett 2011, Kotu et al. 2019); however, each study has a different focus and context from ours. The study by Kotu et al. (2019) assessed profitability of 
improved storage technologies in Tanzania and found that the profitability of storage varied with season. While such information is critical in validating some of the assumptions about the benefits from crop storage, it does not provide information on how farmers make decisions with regard to the seasonal purchasing and selling of grain.

A second motivation in paper is driven by the influence of public interventions in product value chains and financial markets on the way households participate in product markets. Barrett (2008) attributes the 'sell low, buy high' phenomenon to the failure in financial markets. In the absence of the first-best option, rural households facing liquidity constraints, may resort to second-best options such as converting non-cash wealth in the form of food crop grain into cash to resolve their liquidity constraints, even if they know that they will have to purchase grain back later at higher prices.

Governments have implemented a number of initiatives to address liquidity constraints including the provision of input subsidies and credit to producers to increase fertilizers and hybrid seed use and, consequently, increased crop productivity and production (Sibande et al. 2017). In Zambia, the Government of the Republic of Zambia (GRZ) has a history of providing production support through input subsidies to the farmers. In 2011, the year when the data for this study was collected, GRZ spent approximately US\$184 million, equivalent to $0.8 \%$ of gross domestic product, to provide nearly $182,500 \mathrm{MT}$ of fertilizer and $9000 \mathrm{MT}$ of hybrid maize seed to participating farmers at subsidized prices through its Farmer Input Support Programme (FISP) (Mason et al. 2013). Indeed, Mason et al. (2013) report that between 2004 and 2011, FISP accounted for an average of $30 \%$ of total GRZ agricultural sector spending, and $47 \%$ of GRZ agricultural sector Poverty Reduction Programme (PRP) spending.

Several studies covered the impact of subsidies on market participation as sellers (Sibande et al. 2017), but studies on their effect on seasonal market participation are scant, with the exception of Stephens and Barrett (2011). Mason et al., (2013) found that subsidised fertiliser promoted maize intensification and extensification, but they do not explore its impact on market participation. In this paper, we build on their work by exploring an additional mechanism through which input credit and input subsidies may influence seasonal market participation: through increased production of maize and hence increasing sales at both harvest and lean season. The differential impact between harvest and lean season sales will depend on the relative magnitude of storage costs and incremental price change between seasons. Therefore, increased production may not always lead to increased sales in the lean season, especially if storage costs are higher than the incremental value of the stored commodity resulting from seasonal price variations. We explore the role of subsidies for productivity enhancing inputs (fertilizer and seed) and credit on the seasonal participation of maize producers in Zambia. More specifically, we seek to answer to the question if access to subsidised inputs and credit affect seasonal maize sales and purchases among maize producers?

Zambia was chosen for this case study because the government's extensive involvement in the marketing of maize grain and maize-meal provides an opportunity to understand the potential role of price stabilisation policies on seasonal market participation by agricultural households. As in other developing countries, Zambian households experience food price instability. In the presence of credit and insurance market failure, commodity price instability can discourage investments and lead to inefficient resource allocation (Rashid 2007). The GRZ also intervenes in commodity marketing via the Federal Reserve Agency (FRA) in order to stabilise maize prices. Mason et al. (2013) report that in 2011, spending on the maize marketing activities of the Food Reserve Agency (FRA), the other major GRZ agricultural sector initiative, accounted for most of the agricultural sector expenditures. The FRA, a parastatal strategic food reserve/maize marketing board, buys maize at a pan-territorial price that typically exceeds wholesale market prices in major maize-producing areas. It then exports the maize or sells it domestically at prices determined by tender, at auctions, or administratively. In deficit production years, the Agency often imports maize and sells it to select large-scale millers at below-market prices (Mason and Myers 2013). Previous studies (Mason and Myers 2013) have shown that the FRA's activities have raised average market prices and stabilised wholesale maize prices. However, what such studies fail to explain is how government maize marketing policies and subsidies may influence individual farmers' marketing behaviour and the welfare effects thereof. This paper attempts to bridge this gap by examining trends in seasonal market participation in maize markets in the presence of FRA activities.

The third motivation for this paper is that some of the barriers to participation in markets are gendered: femaleheaded households (FHHs) without a spouse may not face the same intra-household gender issues that women in male-headed households (MHHs) do (Marenya et al. 2017). This leads to differences with respect to the manner in which men and women access production resources and consequently how they participate in commodity markets. It also stems from the fact that compared to men, women face a number of constraints including poor training, limited access to market information, as well as less access to productive resources which leads women to lose income in the process of participating in those markets (Kassie et al. 2014; Quisumbing 1995; Gurung 2006). A similar observation is made by Ellis et al. (2006), World Bank (2007) and Bardasi et al. (2007) who show that women-owned enterprises receive less support than those owned by men, hence reducing women's effectiveness as actors in the value chains. Moreover, development literature 
(Marenya et al. 2017; Quisumbing et al. 2014; World Bank 2001) argues in support of gender equity in agricultural development.

One contribution of this paper is to empirically analyse the extent to which FHHs and MHHs exhibit differential seasonal participation in maize markets in Zambia. We seek answers to the question: if resources were equitably distributed between FHHs and MHHs, could equal market participation between them be achieved? Marenya et al. (2017) and Kassie et al. (2014) show that the gender-based disparities in market participation may be driven by either differences in resource endowments or by differences in returns (quality) to these resource endowments. This paper seeks to identify the relative contributions of these two issues to any gaps that might be observed in market participation between FHH and $\mathrm{MHH}$.

The rest of the paper is organized as follows, section 2 presents the theoretical framework for market participation and empirical techniques while section 3 describes the data sources. The results and conclusions are presented in sections 4 and 5 respectively.

\section{Conceptual and methodological framework}

This study follows a theoretical proposition by Stephens and Barrett (2011) to examine seasonal participation in maize markets. According to this framework, seasonal market participation can be explained from a perspective of an agricultural household model. The model is constructed on the assumption of a household that maximises its utility by consuming goods produced on the farm and goods purchased from the market. The seasonality of agriculture puts a household in a situation where it has to decide how to meet its consumption needs in the season soon after harvest which we call the 'harvest season' as well as in the season prior to the next harvest which we call the 'lean season'. Stephens and Barrett (2011) built on a two-period model proposed by Saha (1994) by introducing marketing transaction costs and liquidity constraints on the seasonal optimisation problem for the household. In this paper, we add gender to the model. Thus, we combine the twoperiod household model with the market participation, liquidity constraint literature and gender perspectives into a single model. This makes it easy to distinguish the dynamics of market participation within a year for the liquidity and nonliquidity constrained household and across MHHs and FHHs. A detailed discussion on the two-period model of market participation under liquidity constraints and transaction cost is presented in Stephens and Barrett (2011). According to this model, households are assumed to maximise their utility through choices for the harvest and lean period consumption. The household produces grain in the harvest season, which depends on the quantity of inputs used during the lean season. The household decides how much grain to consume at harvest, how much grain to store until the lean season, and how much of it to sell. The level of consumption at harvest time is thus constrained by the household's full income which is also influenced by the household's level of endowment.

A household optimises its consumption and production decisions over the two seasons depending on the expected harvest and lean season prices. Current consumption is assumed to be decreasing in all own prices as well as in the ratio of current to expected future own prices and increasing in current and future incomes.

The supply of grain for the harvest and lean seasons is assumed to depend on harvest period grain production as well as the amount of grain to store between the harvest and lean seasons which also depends on access to liquidity (ability to borrow).

For a household facing liquidity constraints and with income falling below current consumption requirements, future prices and future income no longer affect consumption choice because stock-out breaks the linkage. Hence the household consumes (direct consumption plus sales) all its available grain, irrespective of expected change in prices over time. As expressed by Stephens and Barrett (2011), the implication of the model of the 'sell low, buy high' phenomenon is that households facing cash constraints will sell soon after harvest at low prices not because they are unaware of the seasonal appreciation in the value of storable grain stocks but, rather, because their current consumption needs force liquidation of their grain, rendering benefits from inter-temporal grain price movements between harvest and lean seasons irrelevant.

Sahu et al. (2004) refer to this phenomenon as a distress sale because farmers tend to sell their agricultural produce below production cost in order to meet their immediate cash needs. Consistent with Parwez (2014), inefficiencies in agricultural supply chains force farmers to sell their produce at throw-away prices, even when prices at retail level are high. In line with this argument, Park (2006) expresses that when the liquidity constraint binds, demand for storage decreases and the household withdraws from its carryover grain supply. In this paper, access to subsidies is assumed to have the same liquidity effect on market participation as access to credit, and thus we test the extent to which access to subsidies affects 'sell low, buy high' behaviour. We also explore if there are any differential effects between MHHs and FHHs.

\subsection{Empirical strategy}

\subsubsection{Analysing determinants of seasonal market participation and the effects of subsidies on market participation}

From the theoretical discussion above, we want to test whether access to subsidised inputs increases the probability of selling maize while decreasing the probability of purchasing maize 
during harvest season when the prices are low. In theory, households that experience liquidity constraints during the harvest period are likely to undertake (relatively expensive) purchases in the lean season and are less likely to sell maize during the lean season when prices are high. Thus, following Stephens and Barrett (2011) we test the hypotheses by empirically exploring the liquidity constraint explanation of the 'sell low, buy high' puzzle. As expressed by Goetz (1992), we can either estimate the models separately for sellers and buyers or estimate it simultaneously. We apply the multivariate probit model to the market participation decision for maize grain sales and purchases in both a harvest and a lean season to capture the relationship between sales and purchase decisions and factors that might influence participation. These include liquidity constraints, gender and other demand and supply related factors, as well as the potential correlation across harvest and lean seasons' participation outcomes. The estimation is based on a system of four market participation decision options/equations $\left(M_{s, n, i}\right)$ per household $i$ where $m_{s, n, i}=\{0,1\}, s=\{$ harvest $(H)$, lean $(L)\}$ and $n=\{$ purchase $(P)$, sale $(S)\}$. The above expression can be fully expressed as:

$M_{i}=\left\{m_{H P, i}, m_{H S, i}, m_{L P, i}, m_{L S, i}\right\}$

Both harvest and lean season purchases include those households that purchased both grain and maize meal. We realise that some were selling maize grain during the harvest period and then buying maize meal in the lean season because maize grain is not readily available in some rural areas during the lean season. About $11 \%$ of the households reported purchasing maize meal. These are taken into account in estimating the prevalence of maize sales followed by later purchases.

Following Key et al. (2000), we assume the decision to participate in a market as a seller or buyer to be dependent upon the time-invariant covariates that influence the shadow price through latent demand or latent supply, as well as factors influencing the household-specific fixed transaction costs that impact the size of the price band around the market price. The full specification for the four potential seasonal market participation outcomes is therefore:

$$
\begin{aligned}
& m_{H P i}^{*}=\beta_{i} x_{i}+\varepsilon_{1}, m_{H P}=1\left(m_{H P i}^{*}>0\right) \\
& m_{H S i}^{*}=\beta_{i} x_{i}+\varepsilon_{2}, m_{H S}=1\left(m_{H S i}^{*}>0\right) \\
& m_{L P i}^{*}=\beta_{i} x_{i}+\varepsilon_{3}, m_{L P}=1\left(m_{L P i}^{*}>0\right) \\
& m_{L S i}^{*}=\beta_{i} x_{i}+\varepsilon_{4}, m_{L S}=1\left(m_{L S i}^{*}>0\right)
\end{aligned}
$$

where $x$ are explanatory variables; $\beta$ are a vector of parameter and $\varepsilon$ are random errors distributed as a multivariate normal distribution with zero mean, unitary variance and an $n \times n$ correlation matrix.

\subsubsection{Analysing market participation gaps between male and female headed households}

We apply the Blinder-Oaxaca decomposition technique adapted for non-linear models (Fairlie 2005) to decompose the differences in the market participation outcomes between MHHs and FHHs. The technique was originally proposed by Blinder (1973) and Oaxaca (1973) and it has been widely used for the analysis of behavioural differences between groups such as in the studies of racial or gender gaps in the labor market literature. It is used to decompose mean differences between an outcome of interest into portions attributable to differences in the distributions of endowments (explanatory variables), and differences in returns to these endowments (coefficients). It allows for the decomposition of the difference between groups into two parts: (i) the part of the outcome differential that is attributed to group differences in the covariates in the two groups, and the part of the outcome differential that is attributed to discrimination or effects of differences in unobserved variables. The decomposition method is conditional on assumptions such as overlapping support and ignorability, required to identify population parameters of interest (Fortin et al. 2011).

\section{Data}

The data collected by the International Maize and Wheat Improvement Center (CIMMYT) are based on a 2011 survey of 1128 households in 35 districts across Zambia (Fig. 1). The target population of this study were the rural households in the major maize growing areas of Zambia. After mapping the district level maize production data four agroecological zones (AEZs) were identified and six provinces (Central, Copperbelt, Eastern, Lusaka, Northern and Southern Province) selected, such that the major maize growing provinces and most of the population was covered. However, maize production in Zone IV was insignificant, hence the sampling focused on three zones. To select a household, a stratified two-stage sampling design was used. The strata were the three agroecological zones, proportionate to the population and maize production (20\% for zone I, $40 \%$ each for the other two zones) in each district. The first stage in each district involved the selection of the standard enumeration areas (SEA) for each agroecological zone in the district. The number of SEAs was proportionate to the population of the agroecological zone. The second stage involved the random selection of 10 households living in that SEA from the list provided by the census bureau.

The questionnaire was administered to the selected households. The questionnaire consisted of 13 modules: household identification, household composition, gender of household head, land ownership and production of HarvestPlus target crops, general maize production and use of previous maize 


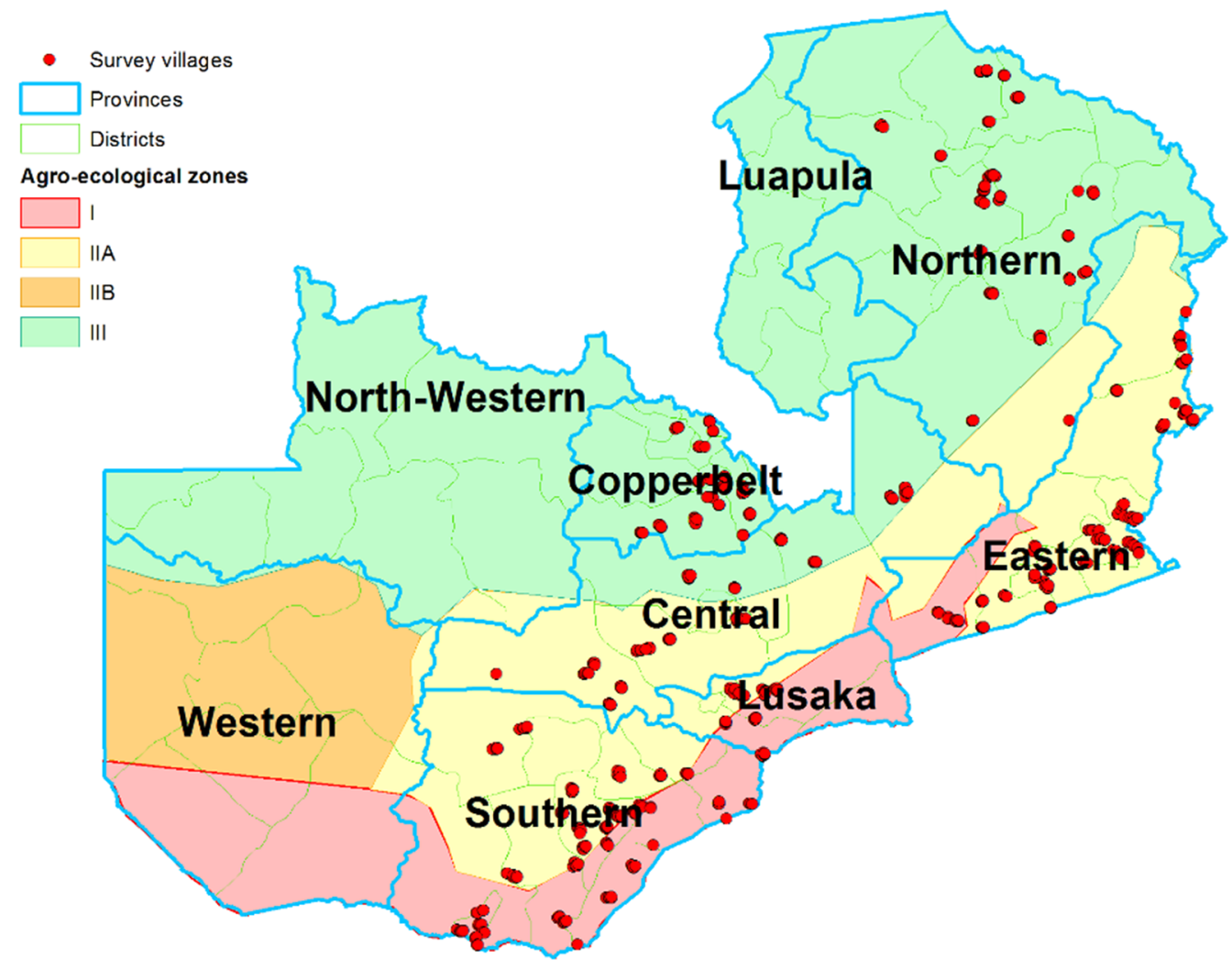

Fig. 1 Agroecological zones and provinces of Zambia where survey were conducted

harvest, maize decision making and labor costs, maize varieties cultivated, and production, consumption and marketing behaviour, including monthly purchases and sales (and associated prices) over the course of the 2010/2011 cropping season. Data was also collected on the receipt of subsidies, access to credit, ownership of livestock, formal education, farm size, household expenditures, and other household assets including housing conditions.

\section{Results and discussions}

\subsection{Household characteristics}

Summary statistics for the surveyed households by the gender of the head of household appear in Table 1. About $47 \%$ of the households sold maize during the harvest season, with significantly more MHHs (49\%) than FHHs (37\%) reporting that they sold maize soon after harvest. About $15 \%$ of the households purchased maize during the harvest season with significantly more FHHs $(20 \%)$ than MHHs (14\%) reporting that they purchased maize.

Maize sales during the lean season were only reported by $3 \%$ of households and more FHHs $(6 \%)$ reported selling maize during the lean season than MHHs (3\%). About a third of households purchased maize in the lean season and there were no significant differences between MHHs and FHHs.

About $25 \%$ of the households were autarkic with more FHHs (30\%) reporting autarky than MHHs (23\%). The autarkic households are those who satisfied their food needs from their own production and did not sell any of their produce. Most farmers reported engaging in agriculture as their main occupation, mainly growing maize.. MHHs had larger land holdings (2.17 ha) compared to 1.5 ha for FHHs. MHHs kept more livestock (5.37 units) than FHHs (2.59 units), and had more members residing in each household (7) than FHHs (6). FHHs were relatively less educated with 5.91 years of formal education compared MHHs whose average years of formal education was 7.3. These differences in factors of production such as land, labour and education can have implications on food production, food security as well as strategies employed by households to meet their food needs.

\subsection{Seasonal participation in maize markets and access to subsidies}

While the data collected captured monthly marketing patterns for the households, we followed Stephens and Barrett (2011) 
Table 1 Descriptive statistics of sample households

\begin{tabular}{|c|c|c|c|c|c|}
\hline & $\begin{array}{l}\text { FHH } \\
N=186)\end{array}$ & $\begin{array}{l}\text { MHH } \\
(N=933)\end{array}$ & $\begin{array}{l}\text { Total } \\
(N=1119)\end{array}$ & Difference & $\begin{array}{l}\mathrm{T}- \\
\text { value }\end{array}$ \\
\hline Sold maize in harvest season (yes $=1$ ) & 0.37 & 0.49 & 0.47 & $-0.12 * * *$ & -2.98 \\
\hline Purchase maize in harvest season $($ yes $=1$ ) & 0.20 & 0.14 & 0.15 & $0.06 * *$ & 2.06 \\
\hline Sold maize in lean season $($ yes $=1$ ) & 0.06 & 0.03 & 0.04 & $0.03 *$ & 1.68 \\
\hline Purchased maize in lean season $($ yes $=1$ ) & 0.36 & 0.33 & 0.33 & 0.03 & 0.77 \\
\hline Purchase maize in both seasons (yes $=1$ ) & 0.19 & 0.09 & 0.13 & $0.10 * *$ & 4.32 \\
\hline Autarkic $($ yes $=1)$ & 0.30 & 0.23 & 0.25 & $0.07 * *$ & 2.03 \\
\hline Sold low and bought high $($ yes $=1$ ) & 0.10 & 0.09 & 0.09 & 0.01 & 0.40 \\
\hline Age of head of household (yrs) & 52.32 & 44.05 & 45.43 & $8.27 * * *$ & 6.91 \\
\hline Household size (persons) & 6.07 & 7.04 & 6.88 & $-0.97 * * *$ & -3.91 \\
\hline Years of education & 5.91 & 7.30 & 7.07 & $-1.39 * * *$ & -4.99 \\
\hline Years of residence in village & 24.99 & 19.34 & 20.28 & $5.65 * * *$ & 4.56 \\
\hline Total livestock units & 2.59 & 5.37 & 4.91 & $-2.78 * * *$ & -2.99 \\
\hline Subsidy $($ yes = 1) & 0.65 & 0.66 & 0.66 & -0.02 & -.432 \\
\hline Proportion who received credit (yes $=1$ ) & 0.04 & 0.02 & 0.02 & $.026 * *$ & 2.212 \\
\hline Farm size (ha) & 1.51 & 2.17 & 2.06 & $-0.65 * * *$ & -3.217 \\
\hline Proportion with iron sheet houses (yes $=1$ ) & 0.46 & 0.47 & 0.47 & -.012 & -0.30 \\
\hline $\begin{array}{l}\text { Proportion whose main occupation is } \\
\text { self-employment (yes }=1 \text { ) }\end{array}$ & 0.02 & 0.01 & 0.01 & .011 & 1.199 \\
\hline $\begin{array}{l}\text { Proportion whose main employment is } \\
\text { casual job }\end{array}$ & 0.01 & 0.01 & 0.01 & -.001 & -.171 \\
\hline $\begin{array}{l}\text { Proportion whose main occupation is } \\
\text { salaried employment (yes }=1 \text { ) }\end{array}$ & 0.02 & 0.03 & 0.02 & -.004 & -.346 \\
\hline $\begin{array}{l}\text { Member of farmer-based organization } \\
\quad(\text { yes }=1)\end{array}$ & 0.64 & 0.70 & 0.69 & -.056 & -1.510 \\
\hline
\end{tabular}

in aggregating market participation into two periods: a harvest period and lean period. For the most part Zambia has one major rainy season that runs from late October to April (a harvesting period of May to August). The data were categorised into (i) 'harvest period' (May to October) and a (ii) 'lean period' (November to April). We then identified household participation in the market by capturing whether or not a household sold or purchased any maize during either of the two periods. In our analysis we focused on participation measured as a dummy variable $(1=$ yes, no = otherwise $)$ because the data on quantities sold or purchased was not collected, hence average quantities could not be calculated for each of the respective periods.

About a quarter of the households did not purchase or sell any grain. Almost half (47\%) sold maize soon after harvest with only $4 \%$ reporting selling maize during the lean season. Similarly, most of the maize and maize- meal purchases $(33 \%)$ occurred in the lean season, while only $15 \%$ of the households purchased maize and maize-meal during the harvest season (Fig. 2). For the $47 \%$ selling maize soon after harvest about $20 \%$ of them purchased the maize grain and maize-meal again in the lean season. Of the $33 \%$ reporting lean purchases, about $40 \%$ of them ( $13 \%$ of the total sample) also purchased maize and maize-meal in the harvest season. This suggests that $13 \%$ of the sample households were not food self-sufficient such that they relied on purchases from the market to meet their food security needs throughout the year. As depicted in Table 1, the reliance on markets for food security in both seasons was more pronounced among FHH (19\%) than MHH (10\%). The attainment of food security for this category of households ultimately depends on the functioning of food markets as well as relevant policies that ensure that food markets do not fail for them.

Figure 3 depicts monthly participation in maize markets for the period of the study. Maize sales are further dis-aggregated

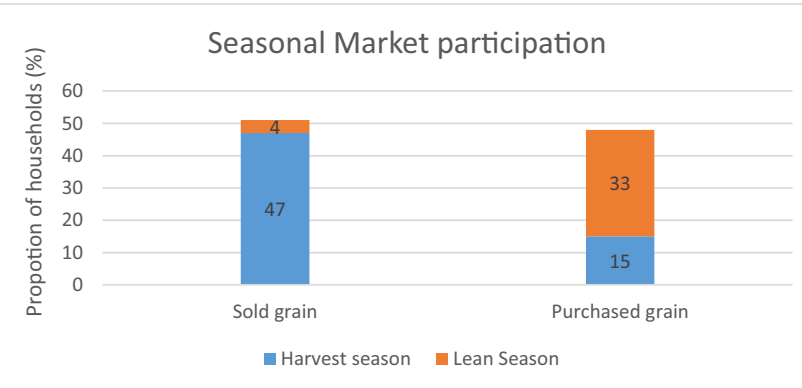

Fig. 2 Seasonal participation in maize markets in Zambia 
Fig. 3 Proportion of households selling maize and buying maize meal and maize grain by season

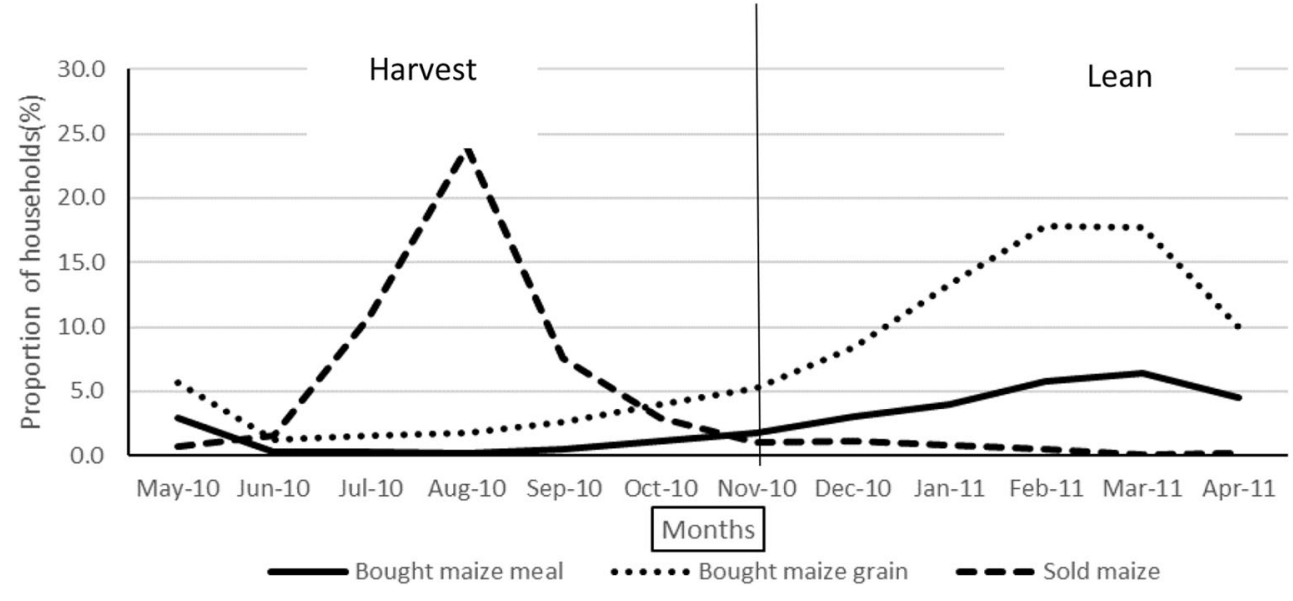

into grain and maize meal sales. Maize selling was popular during the harvest season, reaching its peak in August while few farmers sold maize after December. Both maize grain and maize meal purchases were low in the harvest and lean period.

Figure 4 depicts nominal maize grain prices in Zambia for the year 2011 when the survey was conducted. The figures capture the trend in national average maize prices, but the actual prices vary significantly across provinces.

Average maize grain prices rose by about $21 \%$ between June and September 2011 and by about $10 \%$ between September and December of the same year. Maize meal prices are usually about twice the price of maize grain, and usually follow the same trend. In some years, during the lean season, the Government of Zambia subsidizes the price of maize meal while supporting the price of maize grain through controlled prices offered by the FRA. The FRA sets a pan-territorial indicative price at which it buys maize from individual farmers and cooperatives while allowing private sector traders to purchase maize at prices above or below the FRA price. In deficit production years, the government of Zambia through the FRA sells maize to selected large-scale millers, typically at prices below the cost of commercial importation Chapoto and Jayne (2009).
Therefore, for some rural households, it might make economic sense for them to sell maize grain at harvest to the FRA at better prices, and then buy back artificially cheap maize meal in the lean season, thereby avoiding the problems of storage costs and storage losses. This study accounts for this potential distortion from government intervention in the maize market through what looks like a consumption subsidy of maize meal, however, only $11 \%$ of the households in this study purchased maize meal. Observed maize grain lean season prices were generally higher than prices for the harvest season with maize prices in the lean season averaging ZKW 1.44 per $\mathrm{kg}$ while harvest season prices averaged ZKW 1.19 per kg of grain maize.

The inter-seasonal price differentials are expected to incentivise farmers to store maize soon after harvest and sell it when prices are much better instead of selling soon after harvest.

The monthly mean maize price trends presented in Fig. 2 are provided by the Central Statistical Office (CSO) and they are retail prices, not farm-gate prices. The actual seasonal differences facing rural farm households might even be greater than shown in Fig. 2 because farmers selling to private traders sell at farm-gate prices, which are generally lower than $\mathrm{CSO}$ retail prices. The CSO retail prices in Zambia are usually
Fig. 4 Nominal monthly maize grain prices in Zambia (JanDec 2011). Source: Central Statistical Office (CSO) Monthly Price Bulletin. Found online at http://www.zamstats.gov.zm/gen/ monthly.php

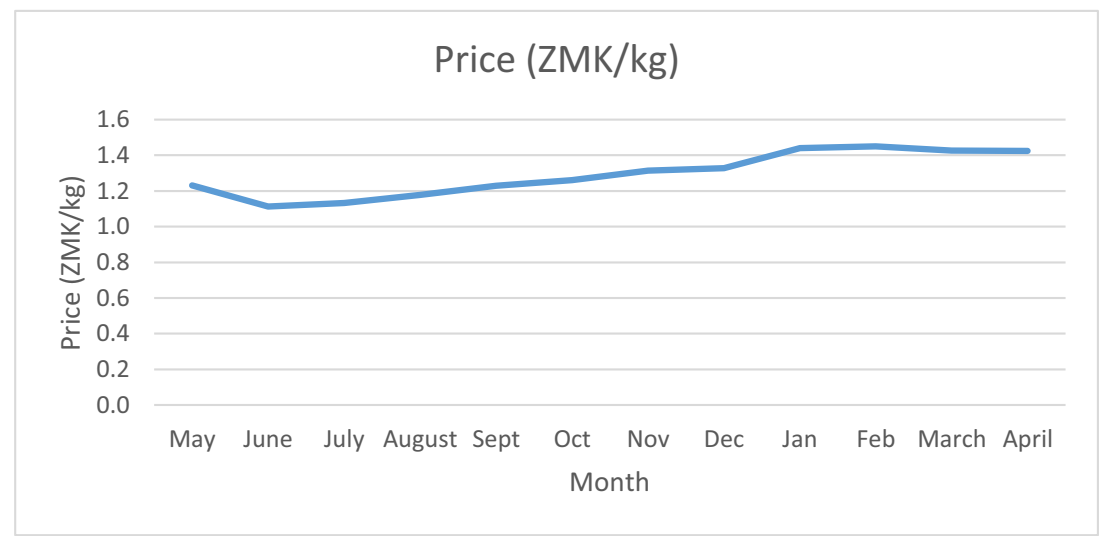


Fig. 5 Buyer of maize and average prices offered to framers

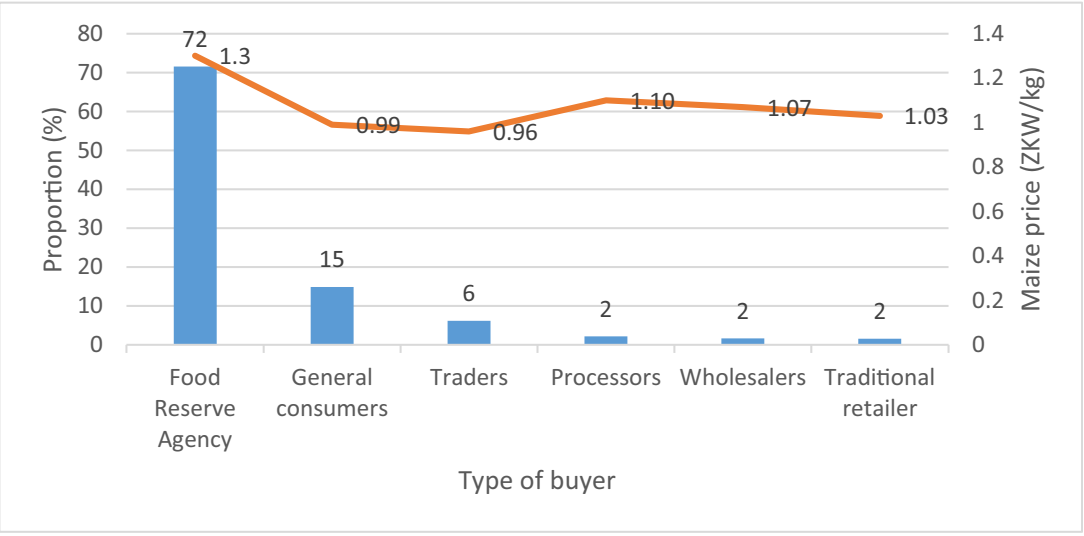

taken as prices that households pay to acquire maize. Above all, many farmers sell maize to the FRA, which offers prices significantly above the market price, and possibly even higher than the CSO retail prices. In this study, about half of the households sold maize. Among those that sold maize, the majority (72\%) sold to the FRA (Fig. 5). This is consistent with Mason and Myers (2013) who report that in 2011, the FRA purchased $83 \%$ of the smallholder maize sales. Regarding the price, farmers that sold their maize to the FRA sold at a higher average price (ZKW 1.3/ kg) than the rest of the buyers.

In order to understand how households are affected by selling at harvest time and buying later in the year, it is important to understand the actual prices that they received and paid - which are not only seasonal, but also household-specific and determined by the type of buyer (whether they sold to the FRA or a private trader etc.), and whether they bought maize grain or maize meal later in the year, and at what price. This also helps discern whether buying grain in the lean season was a problem or an opportunity.

Figure 6 depicts the distribution of purchase and selling prices through the harvest and lean season. The purchase prices for maize meal are consistently higher than the grain prices for both seasons. The selling price for maize grain is slightly higher in the first part of the harvest season and falls below the purchase prices in the second half of the harvest season. However, overall, the two prices are almost equal from January through April when the FRA is out of the market. This is because for most of the harvest season, the FRA intervened in the market and bought maize at a higher price than the price offered by private traders. However, the selling price dropped towards the end of the harvest season as the FRA withdrew from the market. Nonetheless the maize purchase price consistently increased from the harvest season through the lean season before dropping again in the harvest season.

Consistent with Stephens and Barrett (2011),some elements of the 'sell low, buy high' behaviour were undertaken by some households with one in five farmers reporting that they sold maize in the harvest season and purchased it again in the lean season. This suggests that such households sold maize soon after harvest, not necessarily because they expected a surplus from their harvest after taking into account the household consumption needs, but instead in order to meet their immediate cash needs. In this study we also did not see farmers taking advantage of the intertemporal price movements to buy maize at harvest, store it for some months, and resell it in the lean season to benefit from the inter-seasonal terms of trade.

\subsection{Who is 'selling low and buying high'?}

About $10 \%$ of all the households sampled, representing about $20 \%$ of the households that sold maize during the harvest
Fig. 6 Purchase and selling prices for maize grain and maize meal offered to households

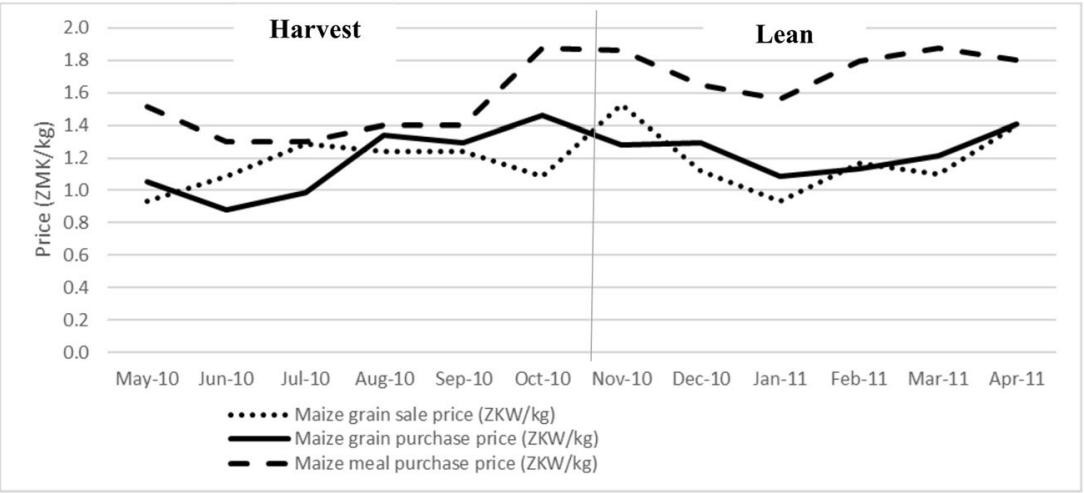


season, reported selling low and buying high. Table 2 depicts characteristics of households disaggregated by whether or not they sold maize at low prices soon after harvest and bought it back at a higher price in the lean season. Households that sold low and bought high had younger heads of households and more persons per household than those that did not. Moreover, households that sold maize early and went back to purchase it in the lean season were largely those who had received subsidised inputs and credit.

These results may suggest that when access to subsidised inputs and credit are considered in isolation, they encourage both postharvest sales and lean purchases. Apparently, household that receive subsidized input and credit are usually the poor households that are also liquidity constrained. The subsidy programme was designed to support very poor and socially disadvantaged smallholders which implies these households were facing cash needs immediately after harvest and used the sales of maize to participate in commodity markets to address their cash needs. As depicted in Table 1, households that sold low and bought high also had significantly lower ownership of iron roofed households, suggesting that they were relatively poor, and they were largely households with memberships in farmer associations.

\subsection{Determinants of market positions}

With seasonal participation in maize markets being the focus of this study, we fit a multivariate probit model of determinants of participation in seasonal markets under different market positions. Results presented in Table 3 show that being a fertiliser subsidy recipient increased the probability of selling maize soon after harvest, both among MHHs and FHHs, but reduced the propensity to purchase maize among MHHs for both the lean and harvest seasons. These findings suggest that subsidies enhanced household food self-sufficiency through increased maize production. Over the years, in the quest to achieve national maize security, farm subsidies have been quite significant in Zambia, with $50-80 \%$ of its agriculture budget allocated to input and output subsidies (Chapoto et al. 2015; Kuteya et al. 2017). During the 2011 season, about two-thirds of the farm households received subsidised inputs in the form of fertilizer and seed (Fig. 7). Results further indicate some variation in the proportion of households receiving input subsidies across provinces with more households in the southern province $(83 \%)$ receiving subsidies than households from Lusaka province $(59 \%)$. These findings provide evidence of the magnitude and impact of the subsidy program on the marketing behaviour of Zambian farmers.

Households with large maize growing areas had a higher propensity to sell maize during harvest season for both MHHs and FHHs (Table 2). Larger maize areas reduced harvest and lean purchases among MHHs, but it only reduced lean purchases marginally among FHHs, suggesting that there are other factors than enhance maize production when interacted with land size among MHHs that are lacking among FHHs. MHHs with older heads of households were less likely to sell maize soon after harvest, while FHHs with older heads of households were more likely to sell maize soon after harvest.

Larger MHHs were associated with increased propensity for lean purchases, while large FHHs were associated with a reduced likelihood for harvest and lean sales, which suggests that being a larger household increased the demand for food for consumption. More years of education was positively and significantly associated with increased participation in lean sales among FHHs.

Table 2 Descriptive statistics of sample households by 'sell low buy high status'

\begin{tabular}{|c|c|c|c|c|c|}
\hline & $\begin{array}{l}\text { Sold low Bought } \\
\text { high }(N=105)\end{array}$ & $\begin{array}{l}\text { did not sell low \& buy } \\
\text { high }(N=1114)\end{array}$ & Total $(N=1119)$ & Difference & T-value \\
\hline Age of head of household & 42.32 & 45.74 & 45.43 & $3.42 * *$ & 2.19 \\
\hline Household size (persons) & 7.38 & 6.82 & 6.88 & $-0.55^{*}$ & -1.74 \\
\hline Years of education & 7.26 & 7.05 & 7.07 & -0.21 & -0.58 \\
\hline Years of residence in village & 20.04 & 20.30 & 20.28 & 0.26 & 0.16 \\
\hline Total livestock units & 5.25 & 4.93 & 4.91 & -0.22 & -0.18 \\
\hline Subsidy & 0.77 & 0.64 & 0.66 & $-0.14 * * *$ & 2.89 \\
\hline Proportion who received credit & 0.07 & 0.021 & 0.02 & $-0.054 * *$ & -3.31 \\
\hline Farm size (ha) & 2.37 & 2.02 & 2.06 & -0.34 & -1.31 \\
\hline Proportion with houses roofed with iron sheets & 0.39 & 0.48 & 0.47 & $-0.019 *$ & -1.75 \\
\hline Gender of head of household $(1=$ male $)$ & 0.82 & .83 & 0.83 & 0.01 & 0.40 \\
\hline Proportion whose main occupation is salaried employment & 0.03 & 0.02 & 0.02 & -0.01 & -0.90 \\
\hline Member of farmer-based organization (yes $=1$ ) & 0.78 & 0.67 & 0.69 & $-0.10 * *$ & -2.15 \\
\hline
\end{tabular}

$* * * p<0.001, * * p<0.05, * p<0.1$ 


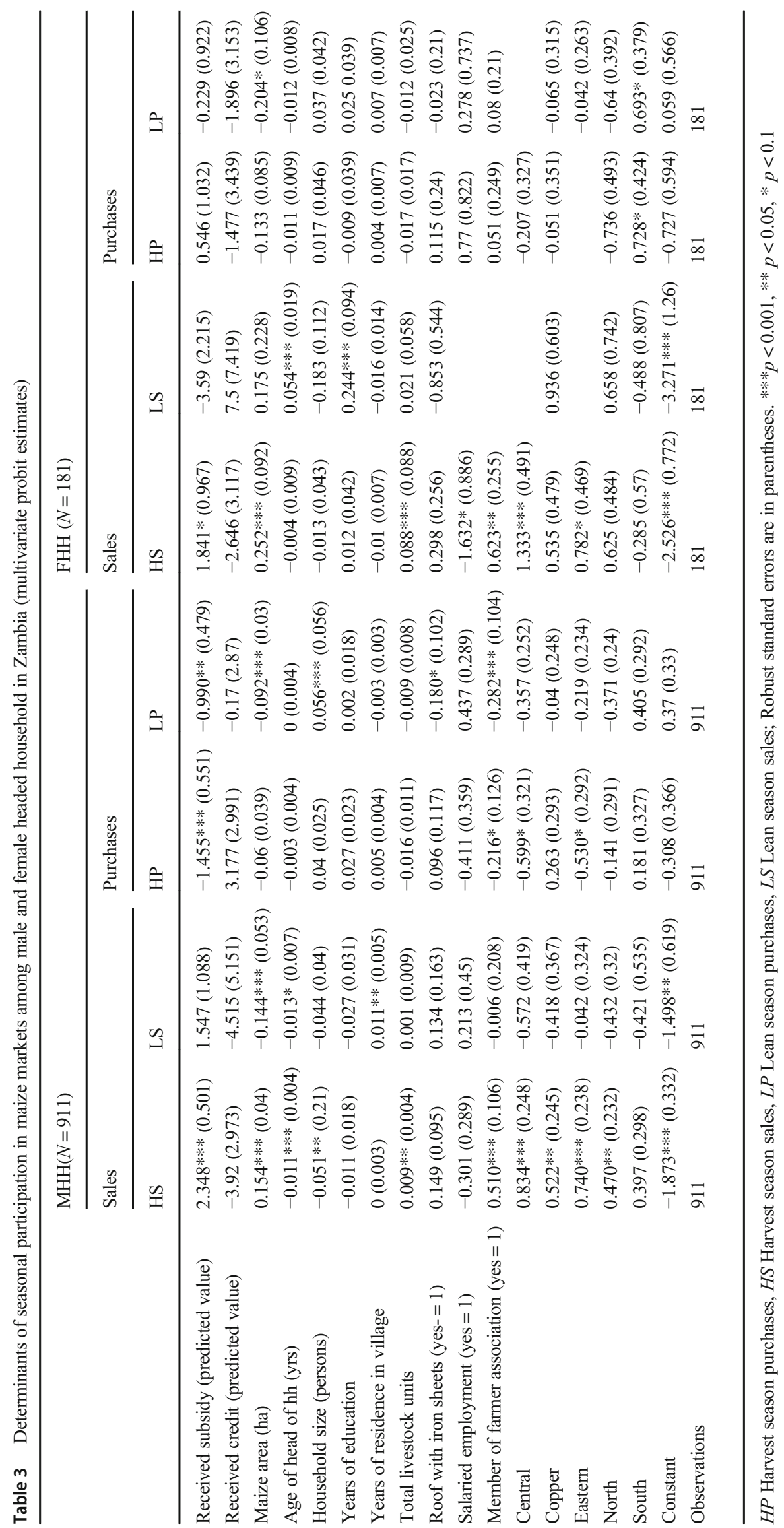


Fig. 7 Proportion of households that received fertiliser subsidies in the 2010-2011 season
Proportion of households (\%) that recieved fertliser subsisdies in Zambia (2011-2012 season)

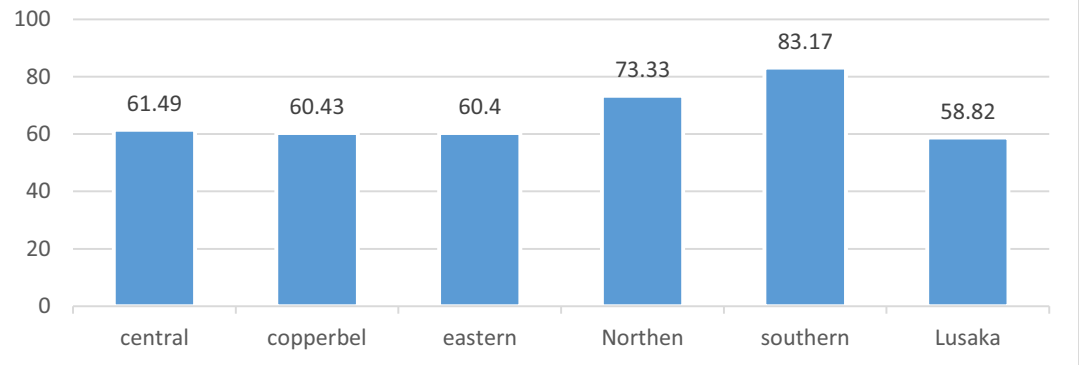

More years of residence in the villages increased the propensity of lean sales among MHHs. This is quite intuitive as the number of years lived in a villages is a good indicator of social capital, and could also imply more knowledge and experience of the price dynamics encouraging those with such knowledge to take advantage of the seasonal price arbitrage.

Greater livestock ownership was positively associated with participation in harvest sales for both MHHs and FHHs, a finding that suggests that increased livestock ownership is associated with increased maize production and household food sufficiency. MHHs whose houses were roofed with corrugated iron, (which is also an indicator of a relatively wealthy household) were less likely to purchase maize during the lean season. The FHHs who reported non-farm casual employment as the main occupation of the household head were less likely to sell any maize soon after harvest. Membership in a farmerbased organization increased for propensity for harvest sales for both MHHs and FHHs while reducing the probability of lean and harvest purchases among MHHs.

\subsection{Decomposition of the seasonal market participation positions by gender of the household head}

We apply the Blinder-Oaxaca technique is to divide the seasonal market participation gaps between MHHs, and FHHs into a part that is explained by differences in determinants of seasonal market participation such as education, age and a part that cannot be explained by such group differences. The decomposition output reports the mean market participation predictions by groups and their differences in the first panel. The results from the decomposition model of the market participation gaps between MHHs and FHHs in the various seasons and market participation categories are presented in Table 4. The mean level of market participation varies significantly between the two groups and across the seasons. There were more MHHs (49.5\%) selling maize after harvest than FHHs (37.6\%), yielding a maize sales participation gap after harvest of about $12 \%$ (column 2). In the second panel of the decomposition output in Table 4, the harvest season sales participation gap is divided into three parts. The first part reflects the mean increase in harvest sales participation among FHH if they had the same levels of resource endowments as MHH. The increase of 0.09 suggests that participation in maize selling during harvest season among FHHs could improve by $9 \%$ if their resource endowments were the same as those of MHH. Overall, about $71 \%$ of the gap in market participation as a maize seller in the harvest season can be explained by the differences in resource endowment.

The second term quantifies the change in FHH's market participation when applying the MHH's coefficients to FHH's resource endowments. The results show that the coefficient effect for harvest sales was not significant, suggesting that applying the MHHs' coefficients to the FHHs' characteristics

Table 4 Linear probability model Oaxaca-Blinder decomposition of the seasonal maize market participation differences between male and female-headed households in Zambia

\begin{tabular}{llllll}
\hline \multirow{2}{*}{ Variables } & \multicolumn{3}{l}{ Sales } & & \multicolumn{2}{l}{ Purchases } \\
\cline { 2 - 3 } \cline { 5 - 6 } \cline { 5 - 6 } & HS & LS & & HP & LP \\
\hline MHH & 0.495 & 0.055 & 0.143 & 0.329 \\
FHH & 0.376 & 0.032 & & 0.204 & 0.363 \\
Difference & $0.119 * * *$ & 0.022 & $-0.062 *$ & -0.035 \\
Endowments & $0.087 * * *$ & 0.000 & $-0.037 *$ & $-0.037 *$ \\
& $(0.028)$ & $(0.005)$ & $(0.020)$ & $(0.020)$ \\
Coefficients & 0.021 & 0.004 & -0.023 & -0.012 \\
& $(0.035)$ & $(0.023)$ & $(0.033)$ & $(0.052)$ \\
Interactions & 0.009 & 0.017 & -0.001 & 0.009 \\
& $(0.022)$ & $(0.017)$ & $(0.003)$ & $(0.040)$ \\
Percent endowment & 0.745 & 0.021 & 0.596 & 1.05 \\
Percent coefficients & 0.177 & 0.206 & 0.370 & -0.990 \\
Percent interaction & 0.076 & 0.772 & 0.016 & 0.295 \\
\hline
\end{tabular}

Boot strap standard errors in parentheses. $* * * p<0.001, * * p<0.05$, * $p<0.1$ 
Table 5 Variables contributing to the harvest season sales market participation gaps

\begin{tabular}{|c|c|c|c|c|c|c|}
\hline & \multicolumn{6}{|c|}{ Individual Variable contributions } \\
\hline & \multicolumn{2}{|c|}{ Endowment effects } & \multicolumn{2}{|c|}{ Coefficient effects } & \multicolumn{2}{|c|}{ Interaction effects } \\
\hline & Coeff. & Bootstrap SE & Coeff & Bootstrap SE & Coeff. & Bootstrap SE \\
\hline Received subsidy & 0.018 & 0.016 & 0.17 & 0.168 & 0.006 & 0.007 \\
\hline Farm size (ha) & $0.031 *$ & 0.018 & -0.03 & 0.034 & -0.013 & 0.019 \\
\hline Years of education (yrs) & $0.017 *$ & 0.009 & -0.002 & 0.006 & 0.005 & 0.012 \\
\hline Total livestock owned & $0.020 * *$ & 0.01 & 0.02 & 0.014 & -0.011 & 0.008 \\
\hline Other controls & Yes & Yes & Yes & Yes & Yes & Yes \\
\hline
\end{tabular}

$* * * p<0.001, * * p<0.05, * p<0.1$ would not significantly change the proportion of FHHs selling maize soon after harvest.

The third term is the interaction term that measures the simultaneous effect of the differences in endowments and coefficients. Consistent with expectation, results show that the effect attributed to the interaction between endowments and coefficients (interaction effect) is not significant. This implies that, where households are selling maize soon after harvest, it is their resource endowment that is responsible for MHHs having a higher probability of selling maize than FHHs.

For the harvest purchases (column 4), more FHHs (20.4\%) purchased maize during the harvest season than MHHs (14.3\%), yielding a maize purchases participation gap after harvest of about $6 \%$. The reduction of 0.037 suggests that participation in maize purchase during harvest season among FHHs could be reduced by $3.7 \%$ if their resource endowments were the same as those of $\mathrm{MHH}$. This has two potential implications: buyers benefit from buying maize in the harvest season when prices are low, hence FHHs buying maize at that time could be doing for strategic reasons of benefiting from price seasonal price differences. However, a second and more likely reason for FHHs purchasing maize soon after harvest is attributed to the fact that they did not produce enough maize to allow them to consume from own production. Therefore, the results suggest that by assigning resources for MHHs to FHHs, FHHs would increase their production of maize, making them food self-sufficient and hence reducing their purchase of maize soon after harvest by $3 \%$. Overall, about $59.6 \%$ of the gap in market participation as a maize-buyers in the harvest season can be explained by the differences in resource endowment.

Neither coefficients nor endowments were significant in explaining the gaps in the probability of selling maize in the lean season in line with the lack of statistical significance in the difference between $\mathrm{MHH}$ and $\mathrm{FHH}$ participation in lean sales.

Table 5 shows specific variables that significantly contributed to the gaps in seasonal participation in maize markets and the results indicate that farm size, years of education and the quantity of livestock owned by the household contributed to the endowment effects portion of the gap between MHHs and FHHs in the selling of maize during the harvest season. The results suggest that participation in maize selling soon after
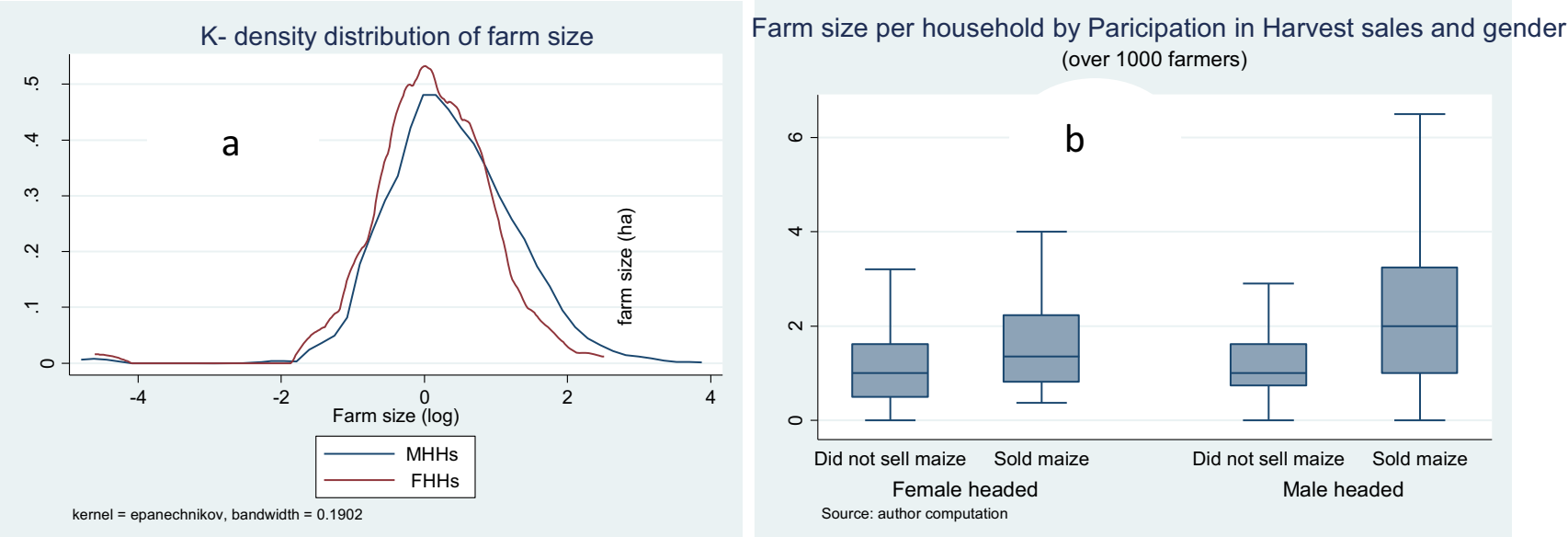

Fig. 8 Kennel density distribution and the farm size among MHHs and FHHs in Zambia 
Table 6 Variables contributing to the harvest season purchase market participation gaps

\begin{tabular}{|c|c|c|c|c|c|c|}
\hline & \multicolumn{6}{|c|}{ Individual Variable contributions } \\
\hline & \multicolumn{2}{|c|}{ Endowment effects } & \multicolumn{2}{|c|}{ Coefficient effects } & \multicolumn{2}{|c|}{ Interaction effects } \\
\hline & Coeff. & Bootstrap SE & Coeff. & Bootstrap SE & Coeff. & Bootstrap SE \\
\hline Received subsidy & 0.004 & 0.005 & -0.179 & 0.138 & -0.007 & 0.007 \\
\hline Farm size (ha) & $-0.019 *$ & 0.011 & 0.003 & 0.006 & 0.007 & 0.011 \\
\hline Total livestock units & -0.005 & 0.008 & 0.023 & 0.016 & -0.012 & 0.009 \\
\hline household size & 0.01 & 0.015 & -0.017 & 0.148 & -0.002 & 0.019 \\
\hline
\end{tabular}

harvest would increase by $3.1 \%, 1.7 \%$, and $2 \%$ if the land, years of education and livestock for MHHs, respectively, were assigned to FHHs. The farm size effect also arises from the fact that MHHs had significantly larger farm sizes than FHHs.

Figure 8 depicts the distribution (A) and the average (B) of the farm size per household for of MHHs and FHHs. The average farm size was higher for MHHs compared to FHHs. The farm size is especially low among FHHs that did not sell any maize during the harvest season and highest among MHHs that did sell maize during the harvest season. The left tail of the distribution (B) further suggests that left skewness was lower for MHHs than FHHs. The Kolmogorov-Smirnov test for equality of distribution functions also demonstrated that the two distributions of farm size between MHHs and FHHs are different.

Table 6 shows specific variables that significantly contributed to the gaps in maize purchases during the harvest season, and the results indicate that farm size, owned by the household, contributed to the endowment effects portion of the gap between MHHs and FHHs in the purchasing of maize soon after harvest. This suggests that the purchase of maize soon after harvest among FMMs would decline by $1.9 \%$, if the land and owned by $\mathrm{MHH}$ was assigned to $\mathrm{FHH}$. This is suggestive of the fact that improving access to land by $\mathrm{FHH}$ makes them maize self-sufficient such that they do not have to rely of markets to meet their household maize requirements.

\section{Conclusions}

Smallholder farmer participation in commodity markets has received increasing interest in recent years, but less attention has been paid to understanding seasonality in the participation. Gender differential in poverty and other welfare indicators has led researchers to explore the extent to which increased market participation can potentially be used to address inequalities in poverty levels between men and women. Using data from Zambia, this paper explores the potential role of government interventions in maize value chains through fertiliser subsidies and through the FRA in reducing the gap in seasonal market participation between MHHs and FHHs. Results show that access to fertiliser subsidies, larger farm size, household size, age of the household heads, years of formal education, and ownership of livestock were significantly associated with participation in the maize markets. Supply enhancing factors such as fertiliser subsidies, farm size and years of formal education increase the probability of selling maize soon after harvest for both FHHs and MHHs while reducing the probability of purchasing maize both in the harvest and lean seasons. Nonetheless, MHHs are $11.8 \%$ more likely to sell maize than FHHs. The gap in maize sales participation between MHHs and FHHs is attributable to a difference in resource endowments such as land size and ownership of livestock, thus suggesting that equalising resource, land and livestock ownership between MHHs and FHHs could potentially reduce the gap by $76.1 \%$. Similarly, the purchasing of maize in both seasons is more pronounced among FHHs, apparently due their low resources endowments. This implies that the existence of gaps in market participation between men and women can be reduced by ensuring equitable access to production resources such as land.

Although the FRA interventions tried to stabilise maize grain prices, there was a general increase in grain prices from the harvest season through the lean season. The 'sell low buy high' behaviour, with some households selling grain at lower prices soon after harvest and buying the same at higher prices in the lean season was observed in about $10 \%$ of the households but the level of participation in this category was the same between MHHs and FHHs. A major limitation of the study is the reliance on information about whether a household sold or bought maize, without capturing the actual quantities of maize sold or purchased. Nonetheless, while the information on quantities could provide more insights on the intensity of market participation, just knowing whether or not one participated in 
the markets is robust enough to provide useful information for a necessary policy intervention.

Acknowledgements The survey was funded by the Bill and Melinda Gates foundation through HarvestPlus and the Stress Tolerant Maize for Africa Project (BMGF Opportunity/Contract ID OPP1134248), and by the CGIAR Research Program on Maize Agrifood Systems (CRPMAIZE).

\section{Compliance with ethical standards}

Conflict of interest The authors declared that they have no conflict of interest.

Open Access This article is licensed under a Creative Commons Attribution 4.0 International License, which permits use, sharing, adaptation, distribution and reproduction in any medium or format, as long as you give appropriate credit to the original author(s) and the source, provide a link to the Creative Commons licence, and indicate if changes were made. The images or other third party material in this article are included in the article's Creative Commons licence, unless indicated otherwise in a credit line to the material. If material is not included in the article's Creative Commons licence and your intended use is not permitted by statutory regulation or exceeds the permitted use, you will need to obtain permission directly from the copyright holder. To view a copy of this licence, visit http://creativecommons.org/licenses/by/4.0/.

\section{References}

Alene, A. D., Manyong, V. M., Omanya, G., Mignouna, H. D., Bokanga, M., \& Odhiambo, G. (2008). Smallholder market participation under transactions costs: Maize supply and fertilizer demand in Kenya. Food Policy, 33(4), 318-328.

Bardasi, E., Blackden, M. C., and Guzman, J. C. (2007) Gender, entrepreneurship and competitiveness in Africa' The Africa Competitiveness Report World Bank.

Barrett, C. B. (2008). Smallholder market participation: Concepts and evidence from eastern and southern Africa. Food Policy, 34, 299 317

Blinder, A. (1973). Wage discrimination: Reduced form and structural estimates. Journal of Human Resources, 8, 436-455.

Burke, M., Bergquist, L. F., \& Miguel, E. (2018). Sell low and buy high: Arbitrage and localprice effects in Kenyan markets. The Quarterly Journal of Economics, 134, 785-842.

Chapoto, A., and Jayne, T. S. (2009) Effects of Maize Marketing and Trade Policy on Price Unpredictability in Zambia. FSRP Working Paper No. 38. Lusaka: Food Security Research Project. Available at http://www.aec.msu.edu/fs2/zambia/wp38.pdf

Chapoto, A., Zulu-Mbata, O., Hoffman, B.D., Kabaghe, C., Sitko, N., Kuteya, A., and Zulu, B. (2015). "The politics of maize in Zambia: Who holds the keys to change the status quo?", working paper, no. 99, indaba agricultural policy research institute (IAPRI), Lusaka, Zambia, October 2015

Ellis, A., Manuel, C., \& Blackden, C. M. (2006). Gender and economic growth in Uganda: Unleashing the power of women. Washington, DC: World Bank

Fairlie, R. (2005). An extension of the Blinder-Oaxaca decomposition technique to logit and probit models. Journal of Economic and Social Measurement, 30(4), 305-316.
Fortin, N., Lemieux, T., \& Firpo, S. (2011). Decomposition methods. In O. Ashenfelter \& D. Card (Eds.), Handbook of labor economics (Vol. 4, pp. 1-102). Amsterdam: North-Holland, Part A.

Goetz, S.J. (1992). A selectivity model of house hold food marketing behavior in sub-Saharan Africa." America.

Gurung, C. (2006). The role of women in the fruit and vegetable supply chain in Maharashtra and Tamil Nadu India: The new and expanded social and economic opportunities for vulnerable groups task order under the women in development IQC. Washington, DC: U.S. Agency for International Development.

Heltberg, R., \& Tarp, F. (2002). Agricultural supply response and poverty in Mozambique. Food Policy, Elsevier, 27, 103-124.

Kassie, M., Ndiritu, S. W., \& Stage, J. (2014). What determines gender inequality in household food security in Kenya? Application of exogenous switching treatment regression. World Development, 56, 153-171. https://doi.org/10.1016/j.worlddev.2013.10.025.

Key, N., Sadoulet, E., \& de Janvry, A. (2000). Transactions costs and agricultural household supply response. American Journal of Agricultural Economics, 82(2), 245-259.

Kotu, B. H., Abass, A. B., Hoeschle-Zeledon, I., Mbwambo, H., \& Bekunda, M. (2019). Exploring the profitability of improved storage technologies and their potential impacts on food security and income of smallholder farm households in Tanzania. Journal of Stored Products Research, 82, 98-109.

Kuteya, N. A., Sitko, N.J., Chapoto, A. and Malawo, E. (2017). An in-depth analysis of Zambia's agricultural budget: distributional effects and opportunity cost, Working paper No. 107, Indaba Agricultural Policy Research Institute (IAPRI), Lusaka, April 2016.

Marenya, P. P., Kassie, M. B., Jaleta, M. D., \& Rahut, D. B. (2017). Maize market participation among female- and male-headed households in Ethiopia. The Journal of Development Studies, 53(4), 481494.

Mason, N. M., \& Myers, R. J. (2013). The effects of the food reserve agency on maize market prices in Zambia', agricultural economics. Vol., 44(2013), 203-216.

Mason, N. M., Jayne, T. S., \& Mofya-Mukuka, R. (2013). Zambia's input subsidy programs. Agricultural Economics, 44(6), 613-628. https:// doi.org/10.1111/agec.12077.

Oaxaca, R. (1973). Male-female wage differentials in urban labor markets. International Economic Review, 14, 693-709.

Park, A. (2006). Risk and household grain management in developing countries. The Economic Journal, 116, 1088-1115.

Parwez, S. (2014). Supply chain dynamics of Indian agriculture: Reference to information technology and knowledge management. Stewart Postharvest Review, 10(1), 01-05.

Pingali, P. (2007). Agricultural growth and economic development: A view through the globalization lens. Journal of Agricultural Economics, 37, 1-12.

Quisumbing, A. R. (1995). Gender differences in agricultural productivity: A survey of empirical evidence. Washington, DC: International Food Policy Research Institute.

Quisumbing, A. R., Meinzen-Dick, R., Raney, T. L., Croppenstedt, A., Behrman, J. A., \& Peterman, A. (2014). Closing the knowledge gap on gender in agriculture. In A. R. Quisumbing, R. Meinzen-Dick, T. L. Raney, A. Croppenstedt, J. A. Behrman, \& A. Peterman (Eds.), Gender in agriculture (pp. 3-27). Dordrecht: Springer.

Rashid, S. (2007). Food price stabilization policies in a globalizing world. Case study \#6-8 of the program: Food policies for developing countries: The role of government in the global food system. Ithaca: Corenll University.

Saha, A. (1994). A two-season agricultural household model of output and price uncertainty. Journal of Development Economics, 45, 245 269. 
Sahu, G. B., Madheswaran, S., \& Rajasekhar, D. (2004). Credit Constraints and Distress Sales in Rural India: Evidence from Kalahandi District, Orissa. The Journal of Peasant Studies, 31(2), 210-241.

Sibande, L., Bailey, A., \& Davidova, S. (2017). The impact of farm input subsidies on maize marketing in Malawi. Food Policy, 69, 190-206.

Stephens, E. C., \& Barrett, C. B. (2011). Incomplete credit markets and commodity marketing behaviour. Journal of Agricultural Economics, 62(1), 1-24.

World Bank. (2001). Engendering development (a World Bank policy research report). Washington, DC: World Bank.

World Bank. (2007). Gender and Economic Growth in Kenya: Unleashing the Power of Women. Directions in development. Washington: World Bank.

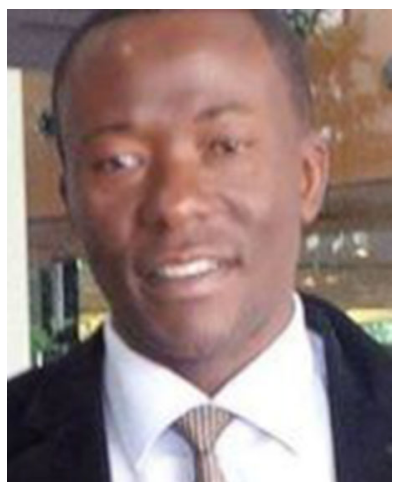

Franklin Simtowe is an agricultural economist with experience in facilitating policy processes, the development of agricultural value chains and in conducting impact assessments and monitoring and evaluation. $\mathrm{He}$ is currently working as a scientist responsible formonitoring and evaluation based at CIMMYT offices in Nairobi.
Hugo De Groote is a principal scientist and agricultural economist with CIMMYT's socioeconomics program in Kenya. He focuses on economic analysis and participatory evaluation, consumer acceptance, experimental methods, policy and institutional analysis. He is based at CIMMYT offices in Nairobi. 